\title{
Natural Resource Management and Low-carbon Transformation
}

\author{
Wang, Shaojian; Shao, Shuai; Giovanni, Baiocchi; Ryberg, Morten
}

Published in:

Resources, Conservation and Recycling

Link to article, DOI:

10.1016/j.resconrec.2020.105018

Publication date:

2020

Document Version

Publisher's PDF, also known as Version of record

Link back to DTU Orbit

Citation (APA):

Wang, S., Shao, S., Giovanni, B., \& Ryberg, M. (2020). Natural Resource Management and Low-carbon Transformation. Resources, Conservation and Recycling, 163, [105018]. https://doi.org/10.1016/j.resconrec.2020.105018

\section{General rights}

Copyright and moral rights for the publications made accessible in the public portal are retained by the authors and/or other copyright owners and it is a condition of accessing publications that users recognise and abide by the legal requirements associated with these rights.

- Users may download and print one copy of any publication from the public portal for the purpose of private study or research.

- You may not further distribute the material or use it for any profit-making activity or commercial gain

- You may freely distribute the URL identifying the publication in the public portal 


\title{
Natural Resource Management and Low-carbon Transformation
}

\author{
Shaojian Wang ${ }^{\mathrm{a}}$, Shuai Shao ${ }^{\mathrm{b}}$, Baiocchi Giovanni ${ }^{\mathrm{c}}$, Morten Ryberg ${ }^{\mathrm{d}}$ \\ a Sun Yat-sen University, China \\ ${ }^{\mathrm{b}}$ Shanghai University of Finance and Economics, China \\ ${ }^{\mathrm{c}}$ University of Maryland, USA \\ ${ }^{\mathrm{d}}$ Technical University of Denmark, Denmark
}

Climate change can be intensified by increased greenhouse gas (GHG) emissions from ineffective use and inappropriate management of natural resources, such as minerals, fossil fuels, and land use (Oyedele et al., 2014). Here, utilization of natural resources, mainly influences the climate in three aspects.

The first is the climate impact of natural resource exploitation and the production of mineral products (e.g., cement). The process of natural resource exploitation, including explosion, mining, extraction, internal transport, lifting, air compression, and water drainage, is highly energy intensive and, thus leading to large GHG emission from the generation of the used energy. Moreover, the production of mineral products is also GHG intensive. For instance, the chemical reactions between raw materials and oxygen during calcination in cement production results in significant carbon dioxide $\left(\mathrm{CO}_{2}\right)$ emissions.

The second aspect is the large GHG emissions associated with the burning of fossil fuels, such as coal, natural gas, and oil for energy generation. According to the Fifth Assessment Report released by the Intergovernmental Panel on Climate Change (IPCC), fossil-fuel-related $\mathrm{CO}_{2}$ emissions reached $32 \mathrm{Gt}$ in 2010 , accounting for nearly $65 \%$ of total GHG emissions in that year (IPCC, 2014). Thus, there is no doubt that reducing $\mathrm{CO}_{2}$ emissions resulting from fossil fuel combustion will make a difference for GHG reduction and climate change mitigation. One effective way to lower fossil-fuel-related $\mathrm{CO}_{2}$ is improving energy efficiency, i.e., achieving the same or higher economic output with less fossil fuel input. Hereby, increased fossil fuel use efficiency will contribute to GHG reduction even if the economy keeps growing. Meanwhile, promoting a substitution of fossil fuels with low-carbon energy is another helpful way to lessen the fossil-fuel-related $\mathrm{CO}_{2}$ emissions. The optimization of the energy structure and improvement of energy efficiency accompanied by increased usage of low-carbon energy can make it possible to satisfy society's energy demand even though fossil fuel burning is reduced. In other words, improving fossil fuel use efficiency and developing low-carbon energy are beneficial for realizing a decoupling of economic growth from GHG emissions (Guan et al., 2018).

The third and last aspect is the impact of land resource management on climate in two aspects. On the one hand, the alteration of land cover by anthropogenic activities will influence terrestrial ecosystems' potential to store carbon and act as a carbon sink-such as vegetation is turned into settlements-due to unparalleled economic development (Chen et al., 2019). Hence, moderated land use structure and improved land use management are essential for addressing the potential climate change effects (Lai et al., 2016). On the other hand, although recent changes in land use were characterized by increasing anthropogenic land cover, improvement of land use efficiency has major impacts on GHG emission reduction. For example, compact development of cities and job-housing spatial match in cities can help reduce GHG emissions. In view of the above effects of natural resource utilization on climate change, more importance must be attached to exerting the low-carbon management of natural resources to render natural resource utilization more climate-friendly. Therefore, some pertinent measures, such as promoting resource tax reforms, formulating carbon taxes, carrying out stricter technological standards, and supporting R\&D on low-carbon technologies, should be taken to improve the exploitation, process, and utilization efficiency of natural resources, develop low-carbon energy, and improve the use of land, in order to actively contribute to mitigating climate change.

For the purpose of better formulating policies that address GHG reductions, a more complete understanding of the low-carbon management of natural resources is needed. This Virtual Special Issue provides an opportunity to achieve more complete analyses and a deeper discussion of how to effectively implement the low-carbon management of natural resources in the task of limiting climate change.

The topics of interest include, but are not limited to:

1. Logical connection and policy design of natural resource management and low-carbon transformation and development;

2. Theoretical framework and practical exploration of low-carbon management of natural resources;

3. Theory and experience of low-carbon management of natural resources in resource-based countries and regions;

4. Performance, potential, and socio-economic costs of low-carbon management of natural resources;

5. Life cycle assessment of technologies and approaches for low-carbon natural resource management;

6. Future trends and scenarios in the context of low-carbon management of natural resources;

7. Pathways and polices of low-carbon management of natural resources. 


\section{Manuscript Preparation and Submission}

A Virtual Special Issue (VSI) is an online-only grouping of Special Issue articles traditionally assigned to a single Special Issue. The articles in a VSI will be assigned a unique identifier and published in a regular journal issue. The unique identifier allows to simultaneously adding the article to a VSI in ScienceDirect.com. Articles grouped together in a VSI retain their original citation details. A VSI speeds up the publication of individual articles, unlike the publication process for conventional Special Issue articles, a VSI does not need to wait for the final article to be ready before publication.

A detailed submission guideline is available as "Guide for Authors" at: http://www.journals.elsevier.com/resources-conservation-andrecycling. All manuscripts and any supplementary material should be submitted through Elsevier Editorial System (http://ees.elsevier.com/ recycl). The authors must select "SI: Climate" in the submission process.

\section{Important Dates}

Full paper submission deadline: November 30, 2020
Final decision notification: April 30, 2021

Publication: As soon as accepted (VSI)

\section{References}

Chen, J., Ju, W., Ciais, P., Viovy, N., Liu, R., Liu, Y., Lu, X., 2019. Vegetation structural change since 1981 significantly enhanced the terrestrial carbon sink. Nature Communications 10, 4259.

IPCC (2014) Climate change 2014: Synthesis report. Contribution of working groups I, II and III to the fifth assessment report of the intergovernmental panel on climate change [Core Writing Team, R.K. Pachauri and L.A. Meyer (eds.)], Geneva, Switzerland.

Lai, L., Huang, X., Yang, H., Chuai, X., Zhang, M., Zhong, T., Chen, Z., Chen, Y., Wang, X., Thompson, J., 2016. Carbon emissions from land-use change and management in China between 1990 and 2010. Science Advances 2 (11) 2016.

Guan, D., Meng, J., Reiner, D., Zhang, N., Shan, Y., Mi, Z., Shao, S., Liu, Z., Zhang, Q., Davis, S., 2018. Structural decline in China's $\mathrm{CO}_{2}$ emissions through transitions in industry and energy systems. Nature Geoscience 11 (8), 551-555.

Oyedele, L.O., Ajayi, S.O., Kadiri, K.O., 2014. Use of recycled products in UK construction industry: An empirical investigation into critical impediments and strategies for improvement. Resources, Conservation and Recycling 93, 23-31. 